\title{
Factors explaining user loyalty in a social media-based brand community
}

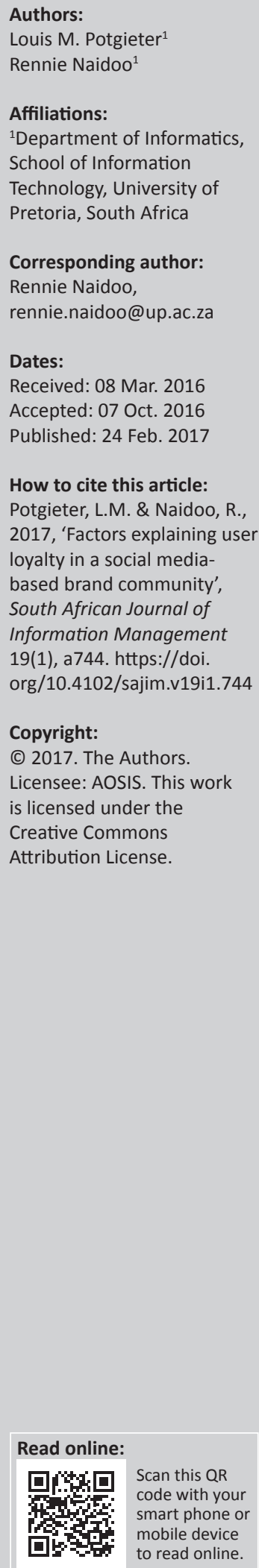

Background: Marketers are interested in taking advantage of the capabilities of social mediabased brand communities to develop long-term relationships with their customers. This research investigated the usage of a South African Facebook page to understand user attitudes and attendant pressures on users related to social norms and user loyalty.

Objectives: The research investigated the extent to which perceived value, service quality and social factors influenced the customer's intention to continue using a global motor vehicle firm's social media-based online brand community (OBC).

Method: We used an online voluntary survey to collect data from social media-based brand community members. In total, 303 responses were collected over a period of 4 weeks from a population of 3100 members. We analysed the relationship between trust, perceived responsiveness, perceived usefulness, perceived ease of use, social norms and the members' intention to continue using the firm's OBC. 293 usable observations were subjected to descriptive, correlation and regression analysis.

Results: The age of the respondents varied from 18 to 58 years with a mean age of 32 years. Of these, $60 \%$ were men and $40 \%$ women. About $86.7 \%$ of the respondents reported having at least some form of tertiary education. The results of the multiple regression analysis indicate that service quality factors such as trust (25.5\%) and social influence factors such as social norms $(12.5 \%)$ explain a greater part of the variance in OBC continuance intention compared with utility factors such as perceived usefulness $(18.2 \%)$. The effects for responsiveness and ease of use were not statistically significant.

Conclusion: Social media-based brand communities are playing an important role in enhancing the overall trust relationship, value offering, sociality, knowledge and information sharing between customers and firms. Practitioners should note that the loyalty of customers using a firm's social media-based brand community is still associated with customers' historical trust in the branded goods or services, and real-world relationships with the firm and brand community members.

\section{Introduction}

The popularity of social media platforms provides firms with the opportunity to build social media-based brand communities (McAlexander, Schouten \& Koenig 2010). Brand communities provide the firm with access to relationships with customers who admire their brand (Muniz \& O'Guinn 2001). Traditional brand communities such as 'brand fests' can be beneficial because firms are able to learn about customer perceptions of new product offerings and the possible outcomes of competitive tactics, attract and collaborate closely with loyal customers, influence customer evaluations and actions, disseminate knowledge and establish a 'holy grail' of loyal customers (Laroche, Habibi \& Richard 2013; McAlexander et al. 2010). In addition, recent innovations in social media-based brand communities provide firms with benefits such as wider customer reach, lower costs and greater communication efficacy (Laroche et al. 2012). However, although there have been a number of studies on offline brand communities, only a few studies have investigated social media-based online brand communities (OBCs).

Social network sites (SNSs) allow people to self-present, to form social networks and to establish and maintain social relationships (Cheung, Chiu \& Lee 2011). For example, Facebook.com was originally meant to connect college students. Now it enables the general masses to connect with virtual groups that share common interests (Ellison, Steinfield \& Lampe 2007). As of the last quarter of 2015, Facebook - now the world's leading online social network service (SNS) - had over 1.5 billion monthly active users (Statista 2015). In South Africa, over the same period, 
Facebook had as many as 12 million monthly active users. Facebook members can now also join virtual groups such as online brand communities (OBCs) (Marchi, Giachetti \& De Gennaro 2011). Despite the critical mass of users on Facebook, user loyalty is a key problem plaguing leading online SNS firms such as MySpace and Friendster (Nielsen 2009). NonSNS firms are also struggling to retain a critical mass of their customers to build sustainable OBCs (Ku, Chen \& Zhang 2013). From a practical standpoint, the benefit of user loyalty is appealing to firms who have social media-based OBCs (Hoffman \& Fodor 2010; Kietzmann et al. 2011). Because the long-term viability of OBCs depend on their continued use (Wang \& Datta 2006; Wang, Xu \& Chan 2008), it is critical that firms understand the factors that drive continuance and loyalty (Viljoen, Dube \& Murisi 2016). Also referred to as OBC revisit, continuance encapsulates the user's actual or behavioural intention to continue regular use of a social media-based OBC (Bhattacherjee 2001a).

The theory of reasoned action (TRA) has been successfully used to predict brand loyalty intention from attitudes and subjective norms (Ha 1998), and thus, it is used as the theory base for this study. This research extends concepts in TRA by developing a research model to study psychological factors that influence users' continuance (loyalty) intention in the context of an OBC. We propose a model in which attitude toward use consists of perceived value (utility) factors including perceived usefulness and perceived ease of use, as well as service quality factors including trust and perceived responsiveness, and subjective norms that include social and interpersonal influence. Using survey data from a single OBC site, we employed regression modelling to assess the model and to test the research hypotheses.

\section{Literature review}

\section{Online brand community loyalty}

The brand community concept is not a novel one. Boorstin (1974:89) used the term 'marketplace communities' to describe consumption communities that shape and maintain what people consume. Muniz and O'Guinn (2001:412) described a brand community as 'a specialized, non-geographically bound community, based on a structured set of social relationships among users of a brand'. McAlexander et al. (2010) provided a more customer-centric perspective of the brand community. They suggest that brand communities exist and are meaningful to customers because of the overall experience they provide rather than because of the brand experience itself. Because marketers are interested in taking advantage of the capabilities of social media-based brand communities to develop long-term relationships with their customers, the main objective of this study is to examine what firms can do to persuade their customers to repeatedly engage with them. There is growing interest among firms to understand the factors that motivate OBC loyalty, that is, factors that lead customers to continue or discontinue using OBCs (Bhattacherjee 2001a). Continuance provides the critical mass of customers needed by the firm to take advantage of the benefits of OBCs. The theoretical support for emphasising continuance comes from relationship marketing theory. This theory emphasises the need to retain existing customers (Grönroos 1996). Relationship marketing theory argues that it is largely in keeping promises that firms develop and maintain long-term relationships. On the contrary, failure to keep promises may lead to defection or discontinuance. Therefore, relationship marketing theory provides significant support for the continuance concept as a key consequent variable.

\section{Perceived value}

Zeithmal (1988:14) defined perceived value as 'the consumer's overall assessment of the utility of a product (service) based on a perception of what is received and what is given'. In another words, perceived value represents the difference between perceived benefits and costs. There is a strong support in the marketing literature that future patronage intentions are determined by perceived value (Caruana et al. 2000). Despite the fact that value plays a significant role in determining customers' choices and their decisions to continue or end a relationship (Ravald \& Grönroos 1996), up to now this concept has received less attention by scholars studying how users use OBCs (Kettinger \& Hu 2008; Ku et al. 2013). The marketing concept of perceived value is similar to the information systems (IS) concept of perceived usefulness. Perceived usefulness is an instrumental and outcome consideration that has been well established in the management information systems (MIS) literature. The technology acceptance model (TAM) by Davis et al. (1989) defines perceived usefulness as the extent to which a user believes that using an IS will enhance their job performance. Other TAM researchers have also supported the view that users will tend to use or not use an IS to the extent they believe it will help them perform their tasks better (Venkatesh, Thong \& Xu 2012). Although the study of perceived usefulness was initially limited to job-related contexts, attributes of perceived usefulness, such as saving time and effort, and providing convenience, have also been applied to the broader online context ( $\mathrm{Lin} \& \mathrm{Lu}$ 2011; Moon \& Kim 2001). Thus, perceived usefulness can be regarded as a measure of the consumer's own perceived costs and benefits of using a technology.

\section{Service quality}

Poor service experience is generally a key reason why many customers defect (Rigby, Reichheld \& Schefter 2002; Zeithaml, Berry \& Parasuraman 1996). One of the earliest definitions of service quality alludes to the difference between what customers expect and what they perceive to be receiving from the firm (Parasuraman, Zeithaml \& Berry 1988). For nearly three decades, both traditional service and IS disciplines have used Parasuraman et al.'s (1988) multiple-item service quality (SERVQUAL) scale for measuring the user's assessment of service quality (Pitt, Watson \& Kavan 1995). The five SERVQUAL dimensions, namely, reliability, responsiveness, assurance, empathy and tangibles, were developed from interpersonal encounters (Parasuraman et al. 1988). 
Some researchers argue that these dimensions may not always be appropriate for information intensive electronic services (Zeithaml 2002). The IS literature argues that information processing should be the focal point for information intensive electronic services (Pitt et al. 1995). In particular, literature studying social media emphasises related issues such as privacy, security, information sharing (Fogel \& Nehmad 2009; Ku et al. 2013) and responsive service support (Adjei, Noble \& Noble 2010) among users of social networking platforms. It appears that trust and responsiveness, on the part of consumers, could illuminate much more about OBC continuance.

\section{Social influence}

Social influence refers to change in a consumer's thoughts, feelings, attitudes or behaviours that arise from interacting with another consumer or group of consumers who share similar norms, values and interests (Burnkrant \& Cousineau 1975; Cialdini \& Trost 1998). Major theoretical models, such as the TAM2 (Venkatesh \& Davis 2000) and the Unified theory of Acceptance and Use of Technology (UTAUT) (Venkatesh et al. 2003), have attempted to account for the role of social influence in technology adoption. Despite theoretical support (Bagozzi \& Lee 2002), empirical findings on the effects of social influence have been inconsistent. Although some recent studies found that social influence has significant effects on an individual's perceived usefulness and behavioural intention to adopt a technology (Wang \& Chou 2014), other studies have been inconclusive (Tsai \& Bagozzi 2014). However, researchers have generally studied social influence in compliance-based use contexts (Chan et al. 2010). Therefore, more research needs to account for the role of social influence in socially enriched voluntary use environments (Naidoo 2014), such as OBCs. Social connectedness and the consumer's needs for belongingness are important for a consumer's psychological sense of community. Social media-based brand communities, in particular, rely on the active participation and interaction of consumers. For example, marketers found that verbal and face-to-face word of mouth (WOM) can be complemented with e-WOM via online OBCs (Gupta \& Harris 2010). The importance of customer experience on OBCs calls for a broader understanding of social relations (Algesheimer, Dholakia \& Herrmann 2005; Carlson, Suter \& Brown 2008; Ellison et al. 2007). However, the subsequent inclusion of social pressure and other cultural factors in technology use studies has yielded limited insights (Venkatesh et al. 2012). Subjective or social norms refer to consumers' perception that most people who are important to them think they should or should not perform the behaviour in question (Ajzen 1991). It refers to the perceived social pressure felt by individuals to perform or not to perform the behaviour. Social norms appears to be an important determinant of intention in the OBC context (Algesheimer et al. 2005; Carlson et al. 2008). Customers may choose to continue using an OBC if they believe that important social referents think they should perform the behaviour, and they are sufficiently motivated to comply with their social referents' behaviour
(Venkatesh et al. 2012). The use of OBCs often implies conforming to social norms (Laroche et al. 2012). Further, because of the intimacy shared among members of a brand community, the social pressure to use the OBC can be particularly high. It is possible that customers might comply with a given behaviour because of their inclination to meet the expectations and pressures exerted by influential social referents (Ha 1998). Therefore, this study expects that social norms will influence the loyal use of OBCs.

\section{Research model and hypotheses The theory of reasoned action}

This research aims to identify the most important cognitive beliefs that predict and explain customer loyalty toward a social media-based OBC. The research model in Figure 1 draws upon Ajzen's TRA from the social psychology literature, where it has been used to study a wide range of individual behaviours (Fishbein \& Ajzen 1975). TRA asserts that a person's behaviour is a conscious reasoned choice influenced by their cognitive thinking and social pressures. The theory postulates that behaviours result from the intention to adopt that behaviour. TRA views intention as a function of the person's attitude and subjective norm toward that behaviour (Ha 1998). It defines attitude as a person's overall positive or negative evaluation about performing the behaviour in question and subjective norm as a person's perception of whether people important to that person expect the person to perform the intended behaviour (Ajzen 1991). These norms come from different referent groups such as friends, family or colleagues at work. Similar to the TRA, which uses intention toward a behaviour as a predictor of the actual behaviour, this study assumes that continuance intention is the best predictor of online loyalty. Therefore, we use continuance intention as a surrogate for OBC loyalty. Bhattacherjee (2001b:352) described continuance as

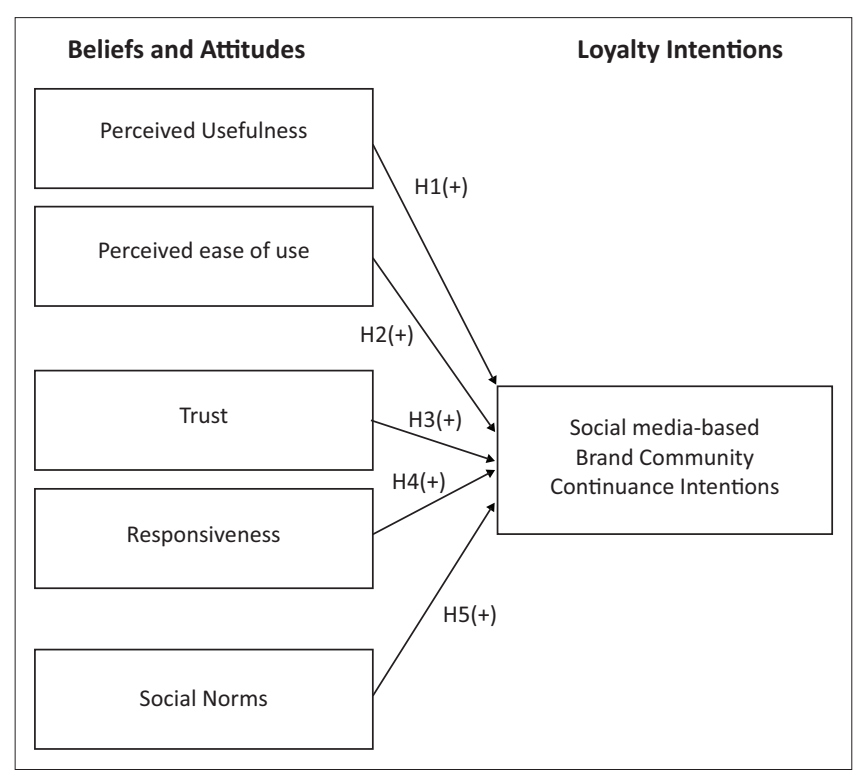

Source: Adapted from $\mathrm{Ha}$ (1998)

$H$, hypothesis.

FIGURE 1: Proposed online brand community loyalty model based on the theory of reasoned action. 
'the existence of a post-acceptance stage when ISs use transcends conscious behavior and becomes part of normal routine activity'. Therefore, this study's model uses continuance intention as the dependent variable (DV).

\section{Hypotheses}

The two prominent factors of the TAM that will be used in this research study are perceived usefulness and perceived ease of use (Davis et al. 1989; Venkatesh et al. 2012). Many researchers have found that if an individual perceives that a certain technology will aid in performing tasks better, their attitude toward that technology use will be positive (Moon \& Kim 2001; Ramayah \& Ignatius 2005; Venkatesh et al. 2012). Some scholars have discovered that users' perceived usefulness also affects positive intention to use social media (Akar \& Mardikyan 2014; Lin \& Lu 2011). Using an $\mathrm{OBC}$ enables a user to acquire more information about the brand, know more about the people in the brand community, improve user efficiency in sharing knowledge and information and connecting with others, and offers a useful way to interact between brand community members (Akar \& Mardikyan 2014). To test if perceived usefulness is a determining factor in relation to social media-based brand communities, the first hypothesis states:

H1: There is a positive association between users' beliefs about the usefulness of a social media-based online brand community and their continuance intention.

Perceived ease of use is described as the degree to which a person believes that using a particular technology would be free from effort (Davis et al. 1989). During the process of accepting the technology, users assess how easy it is to learn how to use the IS in question. Perceived ease of use is likely to increase technology use (Moon \& Kim 2001). Although current literature finds that perceived ease of use is important in the use of social networking sites (Akar \& Mardikyan 2014; Lin \& Lu 2011), this study seeks to investigate its specific impact on social media-based OBCs. This leads to the second hypothesis:

H2: There is a positive association between users' beliefs about the ease of use of a social media-based online brand community and their continuance intention.

Firms that are able to convey trust appear to provide greater levels of service quality (Zeithaml et al. 1996) and repeat patronage (Rigby et al. 2002) than their competitors. Trust plays an important role in all forms of commercial exchanges and is more important in exchanges where one party must exhibit complete faith in another or expose themselves to uncertainty or risk (Gefen, Karahanna \& Straub 2003; Gefen 2000). In the social networking environment, users are often concerned about security, privacy and fraud issues (Dwyer, Hiltz \& Passerini 2007; Laroche et al. 2013; Nyoni \& Velempini 2015). This is further exacerbated by the uncertainty of using the somewhat open Internet infrastructure to interact (Gefen 2000). When compared to traditional services, OBCs are faced with a greater set of challenges to develop trust. Therefore, this research posits that users evaluate the trust they have about the OBC before they form an intention to continue visiting. It follows that:

H3: There is a positive association between users' beliefs about the trust of a social media-based online brand community and their continuance intention.

Responsiveness is defined as the willingness to help customers and provide a prompt service (Parasuraman et al. 1988; Zeithaml 2002). Many researchers have commented on the importance of responsiveness in traditional service firms and other disciplines (Pitt et al. 1995). Previous empirical research also confirms that prompt service is positively associated with purchase intentions, customer preferences and recommendations (Zeithaml 2002). For OBCs, responsiveness also includes post-site service aspects such as issue resolution (Kietzmann et al. 2011; Ramayah \& Ignatius 2005). Responsiveness can be viewed as the firm's ability to respond quickly to the user's requests for support (Bertot, Jaeger \& Grimes 2010) or inquiries on service failures (Mangold \& Faulds 2009). It is conceivable that an OBC that offers acceptable online responsiveness creates positive user continuance intentions. Therefore, it follows that:

H4: There is a positive association between users' beliefs about the responsiveness of a social media-based online brand community and their continuance intention.

Subjective norm is the process where users incorporate a referent's belief into their belief structure (Venkatesh et al. 2012). This implies if the user's peers believe the system should be used, the user will also tend to believe the system should be used (Ramayah \& Ignatius 2005). For instance, users are concerned about their image, that is, the degree to which the use of the system enhances their status in their social group (Hsu \& Chiu 2004). If the user's peers believe that the user should use the social networking site, the user will accept this system to improve his or her image (Ku et al. 2013; Lin \& Lu 2011). In keeping with advances in SNS-based studies, this research study proposes the inclusion of social norms in $\mathrm{OBC}$ use. This leads to the fifth and final hypothesis:

H5: There is a positive association between users' beliefs about the social norms of a social media-based online brand community and their continuance intention.

\section{Research methodology}

The target population of this study was users of a global motor vehicle manufacturing 'Facebook friends' page in South Africa. We complied with the ethics policies of our institution. For instance, we obtained written ethical approval from the collaborating organisation involved in the research. All the participants also acknowledged that they understood the nature and purpose of the research and that they freely consented to participating in the study. Empirical data for hypothesis testing were collected using a self-administered online survey questionnaire. The questionnaire was pretested for content and face validity by four ISs researchers and four marketing practitioners. Only a few minor suggestions 
were made concerning the wording of a few questions. These suggestions were incorporated into a revised instrument. Prior to the main survey, a pilot test was conducted with a convenience sample of 110 of the firm's employees who also had experience with the social media platform. The main objective was to investigate if the full spectrum of the scales was utilised. A number of respondents commented about the structure of the questionnaire. The structure of the questionnaire was changed to ensure the number of questions on each page did not overwhelm respondents.

The final questionnaire was divided into two main sections. Section A dealt with the demographic information of the respondents, which included gender, age, profession and highest educational qualification. Section B measured the research model's six constructs. The measures used were adapted from relevant prior studies. To ensure that the measures were applicable to this study, we modified the questions slightly, changing, for example, the name of the online retailer to 'Facebook page'. Items were measured by using a 7-point Likert scale which ranged from strongly disagree (1) to strongly agree (7). Items for measuring continuance intention were adapted from Bhattacherjee (2001b) and Hsu and Chiu (2004). The construct's three indicators are as follows:

- I intend to continue using the Facebook page rather than to discontinue its use.

- My intentions are to continue using the Facebook page rather than to use any traditional mediums of communication.

- I will regularly use the Facebook page in the future.

Items for measuring perceived usefulness were adapted from Davis et al. (1989). The construct's four indicators are as follows:

- I find the Facebook page useful in finding information.

- The information available is useful.

- The Facebook page is useful.

- My life would be negatively affected if I had no access to the Facebook page.

Items for measuring perceived ease of use were also adapted from Davis et al. (1989). The construct's four indicators are as follows:

- Learning to use the Facebook page was easy.

- Using the Facebook page is easy.

- I find the Facebook page clear and understandable.

- It was easy for me to become skilful at using the Facebook page.

Items for measuring social norms were adapted from Venkatesh et al. (2012). The construct's four indicators are as follows:

- People who influence my behaviour think that I should use the Facebook page.

- People who influence my behaviour suggested that I should use the Facebook page.
- People who are important to me suggested that I should use the Facebook page.

Items for measuring trust were adapted from Gefen et al. (2003). The construct's four indicators are as follows:

- Based on past experience with the Facebook page, I know that the company cares about its customers.

- Based on past experience with the Facebook page, I know that the company is honest.

- Based on past experience with the Facebook page, I know that the company provides good service.

- Based on past experience with the Facebook page, I know that the company is trustworthy.

Items for measuring responsiveness were adapted from Cenfetelli, Benbasat and Sameh (2008). The construct's three indicators are as follows:

- I believe the Facebook page is responsive to my needs.

- If I had to obtain information, I think the Facebook page would give me prompt service.

- The customer service on the Facebook page will address any concerns that I might have.

The main online survey ran over a 4-week period, starting from 2 April 2012 to 30 April 2012. At the time of the survey, the Facebook page had 5263 subscribed users. Participation via a self-administered electronic questionnaire was voluntary. Users were invited to participate on the Facebook page and were provided with a hyperlink to the online survey. A reminder was posted on the same page twice a week for 4 weeks. The user activity rate during this period was measured at approximately 20\% (1032 users). Following a single round of data collection, 303 responses were collected giving a response rate of $29 \%$. Ten of these responses were incomplete and were discarded. The remaining responses were screened to identify any data entry errors as well as for univariate outliers. Of these 293 cases, no cases were found to contain data errors or any outliers. The final data for analysis consisted of 293 usable responses. The number of responses received was considered sufficient based on the number of variables and the techniques that were to be used to test the hypotheses (Hair et al. 1998). The data were analysed using correlation and multiple regression analysis with the aid of Statistical Package for Social Sciences (SPSS) version 15. Standard multiple regression analysis was used to test the hypotheses.

\section{Findings}

Table 1 presents the profile of respondents. The age distribution of the respondents varied from 18 to 58 years with a mean age of 32 years. Of these, $59.7 \%$ were men and $40.3 \%$ women. There was a reasonable spread of male and female respondents. This was not surprising given the broad appeal of this particular motor vehicle brand. The brand positions its range of vehicles in the mid-range and high-end market segments. Respondents' professions varied from $56(19.1 \%)$ that had a career in the finance, 
TABLE 1: Profile of the participants $(N=293)$

\begin{tabular}{lcc}
\hline Participants & Number & $\%$ \\
\hline Gender & 175 & 59.7 \\
Male & 118 & 40.3 \\
Female & & \\
Age group & 109 & 37.2 \\
18-29 & 147 & 50.2 \\
30-39 & 29 & 9.9 \\
40-49 & 8 & 2.7 \\
50-59 & & \\
Profession & 56 & 19.1 \\
Finance & 77 & 26.3 \\
IT & 30 & 10.2 \\
Engineering & 26 & 8.9 \\
Education & 29 & 9.9 \\
Manufacturing & 75 & 25.6 \\
Other & & \\
Highest level of education & 1 & 0.3 \\
Pre-matric & 38 & 13.0 \\
Matric & 69 & 23.5 \\
Diploma & 103 & 35.2 \\
Degree & 74 & 25.3 \\
Post-degree & 8.7 \\
Other & & \\
\hline
\end{tabular}

$77(26.3 \%)$ in information technology, 30 (10.2\%) in engineering, $26(8.9 \%)$ in education, $29(9.9 \%)$ in manufacturing and $75(25.6 \%)$ in other professions. Although respondents had diverse educational levels (high school to doctoral study), $86.7 \%$ of the respondents reported having at least some form of tertiary education.

Principal component analysis (PCA) with a direct oblimin rotation of the 21 Likert scale items reflecting the variables of the study (perceived usefulness, ease of use, social norms, responsiveness, trust and continuance intention) was conducted. Prior to performing PCA, the suitability of the data for factor analysis was assessed. Inspection of the correlation matrix revealed the presence of many coefficients of 0.3 and above. The Kaiser-Mayer-Olkin value was 0.860 . This exceeds the recommended value of 0.60. The Bartlett's test of sphericity reached statistical significance $(p=0.000)$, supporting the factorability of the correlation matrix. Initial PCA revealed the presence of seven factors, with eigen values exceeding 1, explaining $68.9 \%$ of the variance cumulatively. During multiple iterations of PCA, 1 item required elimination because it failed to meet the minimum criterion of having a primary factor loading of at least 1 and cross-loaded highly on more than one factor. The item PU4, 'My life would be negatively affected if I had no access to the firm's Facebook page' loaded strongly with continuance intention scale items. As a result, this item was dropped. A stable 6-factor and 21-item solution emerged and is shown in Table 2.

The Cronbach's alpha test was used to test the internal consistency of the scale items (Hair et al. 1998). Results revealed sufficiently high internal consistency for all scales, ranging from 0.776 to 0.937 . Results of the analysis, along with descriptive statistics (item means and standard deviations), are presented in Table 2.
TABLE 2: Mean, standard deviation and construct reliabilities.

\begin{tabular}{lcccc}
\hline Constructs & Items & Mean & Standard deviation & Cronbach's alpha \\
\hline Usefulness & 3 & 5.36 & 1.13 & 0.907 \\
Ease of use & 4 & 5.54 & 1.08 & 0.828 \\
Social norms & 4 & 4.27 & 1.52 & 0.937 \\
Responsiveness & 3 & 5.22 & 1.05 & 0.820 \\
Trust & 4 & 5.47 & 1.03 & 0.894 \\
Continuance intention & 3 & 5.06 & 1.22 & 0.776 \\
\hline \multicolumn{2}{l}{ Note: All loading were greater than } & 0.60. 7-point scale: 1 = strongly disagree, 7 = strongly
\end{tabular}
agree.

TABLE 3: Correlation matrix for usefulness, ease of use, social norms, responsiveness and trust on $\mathrm{OBC}$ continuance intention $(N=293)$.

\begin{tabular}{lcccccc}
\hline Variables & $\mathbf{1}$ & $\mathbf{2}$ & $\mathbf{3}$ & $\mathbf{4}$ & $\mathbf{5}$ & $\mathbf{6}$ \\
\hline 1. Continuance intention (DV) & 1.0 & - & - & - & - & - \\
2. Usefulness & 0.411 & 1.0 & - & - & - & - \\
3. Ease of use & 0.360 & 0.605 & 1.0 & - & - & - \\
4. Social norms & 0.364 & 0.363 & 0.215 & 1.0 & - & - \\
5. Responsiveness & 0.424 & 0.430 & 0.337 & 0.302 & 1.0 & - \\
6. Trust & 0.444 & 0.221 & 0.209 & 0.339 & 0.525 & 1.0 \\
\hline
\end{tabular}

DV, dependant variable.

Note: Continuance intention is the DV. All correlations are statistically significant at $p<0.01$.

Continuance intention (mean $=5.06, \mathrm{SD}=1.22$ ) scores indicate respondents reacted positively toward using the firm's Facebook page. Scores for perceived usefulness (mean $=5.36$, $\mathrm{SD}=1.13$ ) suggest that the firm's Facebook page generally adds value for the majority of respondents. Perceived ease of use had the highest performance score (mean $=5.54, \mathrm{SD}=1.08$ ). This shows that overall users find the firm's Facebook page easy to use. Scores for social norms (mean $=4.27, \mathrm{SD}=1.52$ ) seem to suggest that users' interaction with the firm's Facebook page is not very strongly influenced by their peers. However, this score did show the most amount of variability in responses. Responsiveness scores (mean $=5.22, \mathrm{SD}=1.05$ ) show that overall users find that the firm responds to their queries. Scores for trust (mean $=5.47, \mathrm{SD}=1.03$ ) performed highly. This indicates that the users perceived the firm as being honest, trustworthy and caring.

Table 3 shows that the scales were tested for independence using Pearson's product-moment correlation. All correlations were significant at $p<0.01$ levels. The relationship between ease of use and usefulness showed a strong, positive correlation between the two variables $(r=0.605, n=293$, $p<0.01)$. This suggests that users' perception of the value of the firm's Facebook page may be influenced by their perception of how easy it is to use the page. Responsiveness appears to have a slightly greater influence on continuance intention $(r=0.424, n=293, p<0.01)$ than usefulness $(r=0.411$, $n=293, p<0.01)$. The correlations between trust and continuance intention $(r=0.444, n=293, p<0.01)$ and social norms and continuance intention $(r=0.364, n=293$, $p<0.01)$ are both moderate. The correlation analysis of responsiveness and ease of use suggests possible mediation relationships with perceived usefulness. Preliminary analyses were performed to ensure no violation of the assumptions of normality, linearity and homoscedasticity (Hair et al. 1998). Intercorrelations among scales did not exceed 0.70, and therefore, the independence of the scales was considered adequate for this study. 
Multiple regression analysis was used to test if the five independent variables significantly predicted the dependent continuance intention variable. The results of the multiple regression analysis in Table 4 reveal that H5: trust $(25.5 \%), \mathrm{H} 2$ : perceived usefulness (18.2\%) and H4: social norms (12.5\%) jointly explain $40.4 \%$ of the variance in social media continuance intention. The technology factor (H3: perceived ease of use) and service quality factor (H1: responsiveness) offered no significant relationship with continuance above that was explained by trust, perceived usefulness and social norms.

\section{Discussion of the findings}

This research examined the effect of the interrelationships between responsiveness, perceived usefulness, ease of use, social norms and trust on the users' continuance intention. The results from the empirical study of the 293 users of a motor manufacturer's Facebook page found support for hypotheses 1, 3 and 5 (Figure 2).

Comparing the above results with prior studies on the loyal use of online technologies, some interesting patterns emerge. Firstly, in this OBC study, social factors such as trust and social norms were stronger predictors of continuance intention when compared with utility factors such as perceived usefulness. This study attests to the growing importance of social factors in the social media context, such as OBCs (Algesheimer et al. 2005; Ellison et al. 2007). Interacting with unknown individuals in an online environment can be unpredictable and present users with overwhelming complexity. Studies have shown that the lack of trust and the absence of social norms in complex online social environments can inhibit a person's intentions to

TABLE 4: Multiple regression analysis of $O B C$ continuance intention.

\begin{tabular}{lcl}
\hline Independent variable & Standardized beta coefficients & Hypothesis testing \\
\hline Trust & $0.255^{*}$ & H5: Supported \\
Perceived usefulness & $0.182^{*}$ & H2: Supported \\
Social norms & $0.125^{*}$ & H4: Supported \\
Perceived ease of use & 0.056 & H3: Not Supported \\
Responsiveness & 0.060 & H1: Not Supported \\
\hline
\end{tabular}

$\mathrm{H}$, hypothesis.

Note: Standardized beta coefficients are shown for the independent variables. $*, p<0.05 ; R^{2}=0.404$.

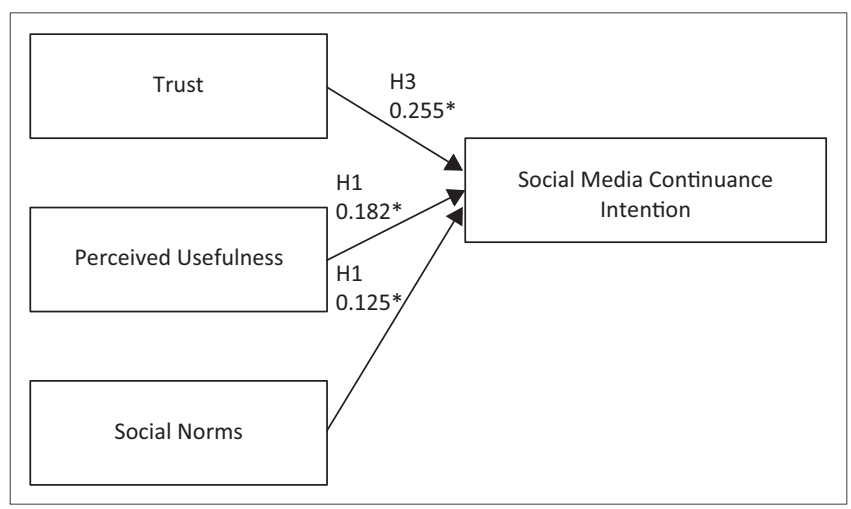

$\mathrm{H}$, hypothesis.

FIGURE 2: Regression model results. perform many behaviours (Gefen 2000; Laroche et al. 2012; Nyoni \& Velempini 2015). Therefore, trust and social norms can also play an important role in risk and complexity reduction in the social media-based OBC context.

Secondly, users place substantial value of the potential benefits of being a member of an OBC. Using an OBC enables a user to acquire more information about the brand, know more about the people in the brand community, improve user efficiency in sharing information and connecting with others, and offers a useful way to interact between brand community members (Akar \& Mardikyan 2014). These findings attest and confirm the importance of utility factors such as perceived usefulness in OBC use contexts (Akar \& Mardikyan 2014; Lin \& Lu 2011; Ravald \& Grönroos 1996).

The direct relationship between perceived ease of use, responsiveness and continuance intention has little or no consequence in social media-based contexts such as OBCs. Past studies have shown that ease of use has an indirect effect on use through the usefulness of technologies (Ramayah \& Ignatius 2005). The findings also suggest that perceived ease of use and responsiveness needs are not that elusive in the social media context. Users may have also gained sufficient experience in using Facebook as well as other social networking sites. Although responsiveness and ease of use may play a less substantial role in this context, it is still important in the users' overall evaluation of whether the OBC is useful.

Our findings are valuable for practitioners. A firm may experience declining usage rates or even complete discontinuance of their OBCs if they fail to take advantage of factors such as trust and perceived usefulness. The first observation in our study is the importance of the level of trust placed in the firm by users. We believe that trust is not only important in enticing the user to join the OBC because of brand familiarity but also crucial in persuading the user to participate continually (Gefen et al. 2003). Our findings also suggest that in interacting via the use of OBCs, management needs to affirm the notion that the firm is honest, that it provides a good service and that it cares about its customers, that is, they should leverage on the trust in their established brands. At the same time, an OBC could strengthen the trust and overall loyalty with the brand on the part of consumers.

Secondly, we believe that management should continually enhance the perceived usefulness of the OBC. In other words, these benefits should not be primarily ad hoc product offers (discounted apparel) but also ongoing communication of rituals (such as regular regional and national brand fests) (Algesheimer et al. 2005).

Thirdly, to stimulate continued use, we believe that managers need to understand how social media is transforming interactions in spaces such as OBCs. The findings suggest that customers that share similar social norms about the brand are more likely to interact with each other in these spaces. Managers need to take advantage of these insights by stimulating interactions between $\mathrm{OBC}$ members and the firm. 
The research study has a few limitations. Firstly, this study focused on one motor manufacturing firm's brand. Although the choice of a single firm controlled for the potential effects of macro-level firm factors (e.g., type of customer segment), we suggest that future studies that incorporate a crosssection of brands should provide a more holistic insight into user continuance. Secondly, this study also suffered from non-response biases inherent in voluntary survey-based research. In this survey, responses were skewed toward those members who were willing to continue using the firm's OBC platform. However, sample demographics (age, gender and education) were comparable with the firm's 'typical' customers. Nevertheless, future studies can also focus on those respondents who discontinued using the OBC platform. Thirdly, although cognitive beliefs were the focal point of this study, affective factors such as satisfaction which were not considered in this study can sometimes be more important in the user's post-evaluation of a technology (Bhattacherjee 2001b). Future studies can integrate the cognitive factors established here with affective factors, to provide a more holistic understanding of OBC loyalty.

\section{Conclusion}

Our study provides evidence that TRA is appropriate to measure different cognitive dimensions that users evaluate when deciding whether to continue using a social mediabased OBC. Data collected from a field survey of 293 social media users of a motor manufacturer's OBC provided partial empirical support for the proposed model. The results supported hypotheses relating to the positive influence of trust, perceived usefulness and social norms on user continuance intentions. The major contribution of this study is that socially related factors such as trust and social norms are two dominant predictors of continuance in the $\mathrm{OBC}$ context. Firms intending to provide a social media-based $\mathrm{OBC}$ are encouraged to prioritise requirements that emphasise the social needs of the users to promote continued use and to enhance overall brand loyalty.

\section{Acknowledgements Competing interests}

The authors declare that they have no financial or personal relationships that may have inappropriately influenced them in writing this article.

\section{Authors' contributions}

R.N. was the study leader and L.M.P. was the Masters student. Both authors made equal contributions in terms of the writing and analysis of this article.

\section{References}

Adjei, M.T., Noble, S.M. \& Noble, C.H., 2010, 'The influence of C2C communications in online brand communities on customer purchase behavior', Journal of the Academy of Marketing Science 38(5), 634-653. http://dx.doi.org/10.1007/ s11747-009-0178-5

Ajzen, I., 1991, 'The theory of planned behavior', Orgnizational Behavior and Human Decision Processes 50, 179-211. http://dx.doi.org/10.1016/0749-5978(91)90020-T
Akar, E. \& Mardikyan, S., 2014, 'Analyzing factors affecting users' behavior intention to use social media: Twitter', International Journal of Business and Social Science 5(11), 85-95.

Algesheimer, R., Dholakia, U.M. \& Herrmann, A., 2005, 'The social influence of brand community: Evidence from European Car Clubs', Journal of Marketing 69(3), 19-34. http://dx.doi.org/10.1509/jmkg.69.3.19.66363

Bagozzi, R.P. \& Lee, K., 2002, 'Multiple routes for social influence: The role of compliance, internalization, and social identity', Social Psychology Quarterly 65(3), 226-247. http://dx.doi.org/10.2307/3090121

Bertot, J.C., Jaeger, P.T. \& Grimes, J.M., 2010, 'Using ICTs to create a culture of transparency: E-government and social media as openness and anti-corruption tools for societies', Government Information Quarterly 27(3), 264-271. http:// dx.doi.org/10.1016/j.giq.2010.03.001

Bhattacherjee, A., 2001a, 'An empirical analysis of the antecedents of electronic commerce service continuance', Decision Support Systems 32, 201-214. http:// dx.doi.org/10.1016/S0167-9236(01)00111-7

Bhattacherjee, A., 2001b, 'Understanding information systems continuance: An expectation-confirmation model', MIS Quarterly 25(3), 351-370. http://dx.doi. org/10.2307/3250921

Boorstin, D.J., 1974, The Americans: The democratic experience, Random House, New York.

Burnkrant, R.E. \& Cousineau, A., 1975, 'Informational and normative social influence in buyer behavior', Journal of Consumer Research 2(3), 206-215. http://dx.doi. org/10.1086/208633

Carlson, B.D., Suter, T.A. \& Brown, T.J., 2008, 'Social versus psychological brand community: The role of psychological sense of brand community', Journal of Business Research 61(4), 284-291. http://dx.doi.org/10.1016/j.jbusres.2007. 06.022

Caruana, A., Caruana, A., Money, A.H., Money, A.H., Berthon, P.R. \& Berthon, P.R., 2000, 'Service quality and satisfaction - The moderating role of value', European Journal of Marketing 34(11/12), 1338-1353. http://dx.doi.org/10.1108/0309 0560010764432

Cenfetelli, R.T., Benbasat, I. \& Sameh, A.-N., 2008, 'Addressing the what and how of Online services: Positioning supporting-services functionality and service quality for business-to-consumer success', Information Systems Research 19(2), 161-181. http://dx.doi.org/10.1287/isre.1070.0163

Chan, F.K.Y., Thong, J., Venkatesh, V., Brown, S.A., Hu, P.J.H. \& Tam, K.-Y., 2010, 'Modeling citizen satisfaction with mandatory adoption of an e-government technology', Journal of the Association for Information Systems 11(10), 519-549.

Cheung, C.M.K., Chiu, P.Y. \& Lee, M.K.O., 2011, 'Online social networks: Why do students use Facebook?', Computers in Human Behavior 27(4), 1337-1343. http://dx.doi.org/10.1016/j.chb.2010.07.028

Cialdini, R.B. \& Trost, M.R., 1998, Social influence: Social norms, conformity and compliance, McGraw-Hill, New York.

Davis, F., Bagozzi, R. \& Warshaw, P., 1989, 'User acceptance of computer technology: A comparison of two theoretical models', Management Science 35(8), 982-1003. http://dx.doi.org/10.1287/mnsc.35.8.982

Dwyer, C., Hiltz, S.R. \& Passerini, K., 2007, 'Trust and privacy concern within social networking sites: A comparison of Facebook and MySpace', Americas The 123(4), 339-350.

Ellison, N.B., Steinfield, C. \& Lampe, C., 2007, 'The benefits of Facebook "friends": Social capital and college students' use of online social network sites', Journal of Computer-Mediated Communication 12(4), 1143-1168. http://dx.doi.org/ 10.1111/j.1083-6101.2007.00367.x

Fishbein, M. \& Ajzen, I., 1975, Belief, attitude, intention and behaviour: An introduction to theory and research, Addison-Wesley Publishing Company, Reading, MA.

Fogel, J. \& Nehmad, E., 2009, 'Internet social network communities: Risk taking, trust, and privacy concerns', Computers in Human Behavior 25(1), 153-160. http://dx. doi.org/10.1016/j.chb.2008.08.006

Gefen, D., 2000, 'E-commerce: The role of familiarity and trust', Omega 28(6), 725-737. http://dx.doi.org/10.1016/S0305-0483(00)00021-9

Gefen, D., Karahanna, E. \& Straub, D.W., 2003, 'Trust and TAM in Online shopping: An integrated model', MiS Quarterly 27(1), 51-90.

Grönroos, C., 1996, 'Relationship marketing: Strategic and tactical implications', Management Decision 34(3), 5-14. http://dx.doi.org/10.1108/00251749610 113613

Gupta, P., \& Harris, J., 2010, 'How e-WOM recommendations influence product consideration and quality of choice: A motivation to process information perspective', Journal of Business Research 63(9), 1041-1049. http://dx.doi. perspective', Journal of Business
org/10.1016/j.jbusres.2009.01.015

Ha, C.L., 1998, 'The theory of reasoned action applied to brand loyalty', Journal of Product \& Brand Management 7(1), 51-61. http://dx.doi.org/10.1108/106104 29810209737

Hair, J.F., Anderson, R.E., Tatham, R.L. \& Black, W.C., 1998, Multivariate data analysis, Prentice-Hall International Inc., Englewood Cliffs, NJ.

Hoffman, D.L. \& Fodor, M., 2010, 'Can you measure the ROI of your social media marketing?', MIT Sloan Management Review 52(1), 41-49.

Hsu, M.-H. \& Chiu, C.-M., 2004, 'Predicting electronic service continuance with a decomposed theory of planned behaviour', Behaviour \& Information Technology 23(5), 359-373. http://dx.doi.org/10.1080/01449290410001669969

Kettinger, W.J. \& Hu, T., 2008, 'Why people continue to use social networking services: Developing a comprehensive model', in ICIS 2008 Proceedings, pp. 1-18. Paper 89 , from http://aisel.aisnet.org/icis2008/89 
Kietzmann, J.H., Hermkens, K., McCarthy, I.P. \& Silvestre, B.S., 2011, 'Social media? Get serious! Understanding the functional building blocks of social media', Business Horizons 54(3), 241-251. http://dx.doi.org/10.1016/j.bushor.2011. Business
01.005

Ku, Y.C., Chen, R. \& Zhang, H., 2013, 'Why do users continue using social networking sites? An exploratory study of members in the United States and Taiwan', Information and Management 50(7), 571-581. http://dx.doi.org/10.1016/j. Information and
im.2013.07.011

Laroche, M., Habibi, M.R. \& Richard, M.O., 2013, 'To be or not to be in social media: How brand loyalty is affected by social media?' International Journal of Information Management 33(1), 76-82. http://dx.doi.org/10.1016/j.ijinfomgt. Information
2012.07.003

Laroche, M., Habibi, M.R., Richard, M.O. \& Sankaranarayanan, R., 2012, 'The effects of social media based brand communities on brand community markers, value creation practices, brand trust and brand loyalty', Computers in Human Behavior creation practices, brand trust and brand loyalty', Computers in
$28(5), 1755-1767$. http://dx.doi.org/10.1016/j.chb.2012.04.016

Lin, K.Y. \& Lu, H.P., 2011, 'Why people use social networking sites: An empirical study integrating network externalities and motivation theory', Computers in Human Behavior 27(3), 1152-1161. http://dx.doi.org/10.1016/j.chb.2010.12.009

Mangold, W.G. \& Faulds, D.J., 2009, 'Social media: The new hybrid element of the promotion mix', Business Horizons 52(4), 357-365. http://dx.doi.org/10.1016/j. bushor.2009.03.002

Marchi, G., Giachetti, C. \& De Gennaro, P., 2011, 'Extending lead-user theory to online brand communities: The case of the community Ducati', Technovation 31(8), 350-361. http://dx.doi.org/10.1016/j.technovation.2011.04.005

McAlexander, J.H., Schouten, J.W. \& Koenig, H.F., 2010, 'Building brand community' Journal of Marketing 66(1), 38-54. http://dx.doi.org/10.1509/jmkg.66.1.38.18451

Moon, J. \& Kim, Y., 2001, 'Extending the TAM for a World-Wide Web context', Information \& Management 38(4), 217-230. http://dx.doi.org/10.1016/S03787206(00)00061-6

Muniz, J. \& O'Guinn, T.C., 2001, 'Brand community', Journal of Consumer Research 27(4), 412-432. http://dx.doi.org/10.1086/319618

Naidoo, R., 2014, 'Who am I online? Examining voluntary use as symbolic-collective action', The Information Society 30(5), 335-348.

Nielsen, 2009, Nielsen's Social Media QuickTake: May 2009, viewed 15 January 2014 from http://www.nielsen.com/content/dam/corporate/us/en/newswire/uploads/ 2009/06/nielsen_pr_090619.pdf

Nyoni, P. \& Velempini, M., 2015, 'Data protection laws and privacy on Facebook', SA Journal of Information Management 17(1), 1-10. https://doi.org/10.4102/sajim. v17i1.636

Parasuraman, A., Zeithaml, V.A. \& Berry, L.L., 1988, 'SEVQUAL: A Multiple-Item Scale for measuring consumer perceptions of service quality', Journal of Retailing 64(1), $12-40$.
Pitt, L., Watson, R. \& Kavan, C., 1995, 'Service quality: A measure of information systems effectiveness', Management Information Systems Quarterly 19(2), systems effectiveness', Management Informa

Ramayah, T. \& Ignatius, J., 2005, 'Impact of perceived usefulness, perceived ease of use and perceived enjoyment on intention to shop Online', ICFAI Journal of Systems Management (IJSM) 3(3), 1-16.

Ravald, A. \& Grönroos, C., 1996, 'The value concept and relationship marketing', European Journal of Marketing 30(2), 19-30. http://dx.doi.org/10.1108/03090 569610106626

Rigby, D.K., Reichheld, F.F. \& Schefter, P., 2002, 'Avoid the four perils of CRM', Harvard Business Review 80(2), 101.

Statista, 2015, Number of monthly active Facebook users worldwide from 3rd quarter 2008 to 3rd quarter 2014 (in millions), viewed 01 February 2016, from http:// www.statista.com/statistics/264810/number-of-monthly-active-facebook-usersworldwide/

Tsai, H.-T. \& Bagozzi, R.P., 2014, 'Contribution behavior in virtual communities: Cognitive, emotional, and social influences', MIS Quarterly 38(1), 143-163.

Venkatesh, V. \& Davis, F.D., 2000, 'A theoretical extension of the technology acceptance model: Four longitudinal field studies', Management Science 46(2), 186-204.

Venkatesh, V., Morris, M.G., Davis, G.B. \& Davis, F.D., 2003, 'User acceptance of information technology: Toward a unified view', MIS Quarterly 27, 425-478.

Venkatesh, V., Thong, J.Y.L. \& Xu, X., 2012, 'Consumer acceptance and use of information technology: Extending the unified theory', MIS Quarterly 36(1) 157-178.

Viljoen, K.L., Dube, L. \& Murisi, T., 2016, 'Facebook versus Twitter: Which one is more credible in a South African context?', SA Journal of Information Management 18(1), 1-7. http://dx.doi.org/10.4102/sajim.v18i1.718

Wang, D., Xu, L. \& Chan, H., 2008, 'Understanding users' continuance of Facebook: The role of general and specific computer self-efficacy', in ICIS 2008 Proceedings. Paper 168, from http://aisel.aisnet.org/icis2008/168

Wang, E.S.-T. \& Chou, N.P.-Y., 2014, 'Consumer characteristics, social influence, and system factors on Online group-buying repurchasing intention', Journal of Electronic Commerce Research 15(2), 119-132.

Wang, Y.K. \& Datta, P., 2006, 'Understand IS continuance: A technology commitment perspective', in ICIS 2006 Proceedings. Paper 77, from http://aisel.aisnet.org/ icis2006/77

Zeithmal, V.A. 1988. Consumer perceptions of price, quality and value: A means-end model and synthesis of evidence. Journal of Marketing 52(3), 2-22.

Zeithaml, V.A., 2002, 'Service excellence in electronic channels', Managing Service Quality 12(3), 135-139.

Zeithaml, V.A., Berry, L. \& Parasuraman, A., 1996, 'The behavioral consequences of service quality', Journal of Marketing 60, 31-46. 